\author{
Mariola Piszczatowska-Oleksiewicz \\ Instytut Stosowanych Nauk SpoŁecznych UW \\ E-MAIL: MPISZCZATOWSKA@O2.PL
}

\title{
POLSCY GNIAZDOWNICY. O POWODACH, DLA KTÓRYCH DOROSŁE DZIECI MIESZKAJĄ Z RODZICAMI
}

\section{Wprowadzenie}

Zaledwie potoczna wiedza na temat biografii jednostki przynosi świadomość, że życie człowieka toczy się według etapów postępujących z upływem lat, jak również pojawiającymi się nowymi celami, wyzwaniami i obowiązkami. Ta sama podstawowa wiedza pozwala wyróżnić w życiu człowieka okres, kiedy następuje zerwanie $\mathrm{z}$ młodzieńczymi postawami, adolescencją, niedojrzałością, zależnością od rodziców na rzecz samodzielności i dorosłości. W tym czasie bowiem jednostka osiąga swoją autonomię, uniezależnia się finansowo od swoich opiekunów (rozpoczyna pracę i zarabia na swoje utrzymanie), opuszcza dom, angażuje w dojrzałe relacje partnerskie, a często też zakłada własną rodzinę. Przedstawione zachowania - tym razem w naukach nad cyklem życia - są traktowane jako wskaźniki cezury dorosłości. Nie sposób dziś precyzyjnie wskazać na wiek, w którym zmiany te miałyby nastąpić, stąd uznaje się, że jest on ruchomy i zmienia wraz z utrwaleniem się nowych prądów dotyczących życia jednostki i życia rodzinnego w otaczającym świecie. Ponadto, wymienione życiowe wydarzenia rozpatrywane pojedynczo nie stanowią kryterium osiągnięcia dorosłości. Prowadzone niedawno w Stanach Zjednoczonych badania ${ }^{1}$ nad dorosłością pokazały, że młodzi Amerykanie postrzegają „osiągnięcie dorosłości” często w kategoriach indywidualistycznych i psychologicznych, takich jak „branie odpowiedzialności za swoje działania”, „podejmowanie decyzji w oparciu o własne przekonania i wartości”, „partnerskie stosunki z rodzicami” czy „uniezależnienie się od wpływu rodziców, czy innych osób”. Jednocześnie odrzucają kryteria, takie jak: „zakończenie edukacji”, „rozpoczęcie pracy zawodowej”, „małżeństwo” i „rodzicielstwo” [Gurba 2000: 202]. Wspólnym mianownikiem wcześniejszych analiz i nowej perspektywy badawczej (opie-

1 Badania młodzieży amerykańskiej (między 18 a 28 rokiem życia), prowadzone przez A. Jansen [1997]. 
rającej się na opinii młodych) jest wskazanie usamodzielnienia od rodziców, jako znaczącym kryterium dla „bycia osobą dorosłą”. Pamiętamy jednak, że wspomniana niezależność, choć jest warunkiem koniecznym do osiągnięcia dorosłości, to nie jest jeszcze wystarczającym. Mimo nadmienionych trudności, istnieją zdarzenia, których obecność w życiu jednostki może ukazywać niezdolność człowieka do wejścia w dorosłe życie. Tym symptomatycznym zdarzeniem jest między innymi odraczanie momentu separacji od rodziny pochodzenia, zwane gniazdowaniem.

Gniazdowanie to nie tylko wygoda, to również bezpieczeństwo, które pozwala korzystać z życia i doświadczać go w nieskrępowany sposób. Dorosłe dzieci mieszkające z rodzicami pod jednym dachem mają swój azyl, swoją przystań, do której zawsze mogą wrócić, podejmując jednocześnie próby wejścia w dorosłość. Bywa jednak, że jest to życiowa konieczność lub „układ” podyktowany rodzinnymi relacjami (w tym oczekiwaniami i wymaganiami rodziców). $\mathrm{Z}$ uwagi na przedłużanie pobytu w rodzinnym gnieździe nazywa się ich gniazdownikami, a efekt rozciągniętego w czasie związku z opiekunami określa się jako zatłoczone gniazdo (cluttered nest/crowded nest), [Boyd, Pryor 1989; Boyd, Morris 1999]. Tytułowy termin pochodzi od gatunku ptaków, których pisklęta po wykluciu nie są zdolne do samodzielnego życia i wymagają stałej opieki rodziców, w związku z czym dłużej pozostają w gnieździe. „Problem nieumiejętności czy też niechęci «odcięcia pępowiny» został zauważony już w latach osiemdziesiątych przez amerykańskich badaczy J. Jill Suitor i Karla Pillemera”, a w polskiej socjologii terminem „gniazdowniki” jako pierwszy posłużył się Tomasz Szlendak, opisując sytuację dorosłych ludzi, którzy z różnych powodów nie chcą wyfrunąć z gniazda [Szlendak 2010: 181]. Gniazdowników często zalicza się do grona dorosłych dzieci, czyli osób w pełni dojrzałych z fizycznego czy prawnego punktu widzenia ${ }^{2}$, jednak mentalnie lub finansowo zależnych, pozostających pod kuratelą rodziców, a więc nadal dzieci. Według postulatów Stauber i Walthera [2001: 3], wspomniana zależność od opiekunów (ekonomiczna lub psychologiczna) nie pozwala zaklasyfikować jednostki jako osoby dorosłej. I choć gniazdowanie jest postawą właściwą jednostce, należy pamiętać o jej rodzinnym charakterze. Innymi słowy, życie jednostki wpisane jest w historię życia rodzinnego, która w rezultacie tworzy koncept połączonych biografii.

2 Większość nowoczesnych państw posiada prawnie określoną granicę wieku, po przekroczeniu której obywatel staje się pełnoletni, bez żadnej wymaganej demonstracji gotowości do wejścia w dorosłość. Pełnoletniość, w tym przypadku, rozumiana jest jako dorosłość z prawnego punktu widzenia. Osoba, która spełni wspomniany warunek wiekowy, nabywa pełnię praw i obowiązków obywatelskich. W Polsce granicą jest osiągnięcie 18 roku życia. Pełnoletniości nie należy jednak utożsamiać z dorosłością psychiczną czy społeczną, które nas szczególnie interesują [Piszczatowska-Oleksiewicz 2011: 76] . 
W obrębie familii stale dochodzi do interakcji oraz negocjowania ról między jej członkami. Pozostawanie dorosłego dziecka w domu rodziców, zdaniem Herberta i Irene Goldenbergów, jest sygnałem, że rodzina zatrzymała się w rozwoju i przejawia trudności w negocjowaniu zmiany. Z tej perspektywy opuszczenie domu rodzinnego przez dzieci wywiera wpływ na życie rodziców, przebieg ich socjalizacji trzeciorzędowej i stawiane zadania. Jednym $\mathrm{z}$ ważniejszych jest renegocjacja systemu małżeńskiego jako diady. Rodzice zostają sami ze sobą. Następuje przesunięcie budowanej przez lata relacji ze związku rodzic-dziecko ponownie, jak na początku związku, na relację mąż-żona, partner-partnerka. Zatroskani rodzice na nowo mogą zająć się sobą. Przez lata inwestowali swoją energię, czas i środki w opiekę, rozwój i kształcenie dzieci, przychodzi więc czas na odpoczynek oraz zadbanie o siebie nawzajem i swoje zdrowie. Opiekunowie powinni zaakceptować autonomię swoich dzieci i ich niezależną rolę. Ważny jest w tym układzie rozwój relacji z dorosłymi dziećmi (zgoda na „wyfrunięcie z gniazda”, radzenie sobie $\mathrm{z}$ „pustym gniazdem”) oraz przegrupowanie relacji tak, by włączyć do rodziny nowych członków - partnerkę lub partnera swojego dorosłego dziecka, a w perspektywie również ich potomstwo. Gniazdowanie można - zdaniem autorów - uznać za przejaw stresu przeżywanego przez rodzinę w czasie zdarzenia przełomowego, jakim jest opuszczenie rodzinnego gniazda, zaś z pozycji osoby - za problem z przyswojeniem konkretnych zadań rozwojowych, które przed nią stoją [Goldenberg, Goldenberg 2006].

Przytoczone głosy, zdaniem których odraczanie momentu wyprowadzki od rodziny pochodzenia jest dysfunkcjonalne tak dla rodziny, jak i jednostki, wymagają, moim zdaniem, szczególnej uwagi i przemawiają za zainteresowaniem się tematem gniazdujących młodych Polaków.

W niniejszym artykule staram się zrealizować zamierzenia poznawcze i eksplikacyjne w całości poświęcone gniazdownikom. Chciałabym rozpoznać istnienie modelu i charakterystycznych dla niego postaw w społeczeństwie w wymiarze demograficznym oraz socjologicznym. W tym celu przedstawię wyniki przeprowadzonych w latach 2005 - 2010 badań $^{3}$ dotyczących problematyki

\footnotetext{
W artykule zostaną przedstawione wyniki trzech przeprowadzonych przeze mnie badań: (1) badania zrealizowanego przez CBOS w czerwcu 2005 roku w ramach „Aktualne problemy i wydarzenia” na reprezentatywnej próbie losowej dorosłych Polaków N=1005, (2) badania zrealizowanego przez TNS OBOP w lipcu 2010 roku w ramach syndykatu „Omnimas” na reprezentatywnej próbie losowej dorosłych Polaków N=949, (3) badania jakościowego w formie wywiadów pogłębionych w następujących miejscowościach: Białystok, Ciechanów, Gliwice, Katowice, Łapy, Poniatowa, Radonice, Tychy, Warszawa, Wrocław) od lipca do października 2013 roku (24 IDI - z gniazdownikami i ich rodzicami).
} 
młodych ludzi funkcjonujących w opisanym układzie „zatłoczonego gniazda”, jak również analizę danych zastanych [Eurostat] ${ }^{4}$.

W artykule podjęłem próbę odpowiedzi na następujące pytania: czy w polskim społeczeństwie mamy do czynienia z syndromem młodych dorosłych odraczających separację od opiekunów? Jakie są powody, dla których młodzi pozostają pod jednym dachem $\mathrm{z}$ rodzicami?

\section{Tendencje ponowoczesne społeczeństwa polskiego jako zachęta do gniazdowania na tle transformacji}

Komentując etapy życia jednostki i rodziny nie sposób robić to bez odwołania do panujących realiów (okoliczności makrospołecznych i historycznych). Przeobrażenia obejmujące swoim zasięgiem współczesne społeczeństwa w tym od ponaddwudziestu lat również polskie - wywierają znaczący wpływ na sferę życia rodzinnego i jednostkowego, a więc również na czas i naturę separacji dorosłych dzieci od opiekunów.

Zagraniczna literatura przedmiotu brak pośpiechu do usamodzielnienia tłumaczy między innymi wydłużającym się procesem kształcenia, potrzebą samorealizacji, trudnościami z podjęciem pracy zawodowej pozwalającej na finansową niezależność w warunkach kryzysu gospodarczego, odraczaniem małżeństwa (na przykład z powodu lęków odziedziczonych po nieudanych doświadczeniach rodziców), możliwością partycypacji w alternatywnych formach życia społeczno-małżeńskiego (na przykład kohabitacją, życiem w pojedynkę), oddzieleniem życia seksualnego od prokreacji i małżeństwa, jak również przeobrażeniami w postawach rodziców wobec swoich dzieci (infantocentryzmem, liberalizacją stosunków, solidarnością międzypokoleniową albo strachem przed pustką, która wypełni dom, kiedy odejdą dzieci), [Walther 2006; Mitchell 2005; Brannen, Nielsen 2002; Boyd, Norris 1999; Tillmann 1996; Jones 1995; Buchmann 1989].

W dobie globalizacji zachowania te stanowią podstawę do naśladowania dla młodych ludzi również w Polsce. Rodzima literatura przedmiotu coraz częściej podejmuje problemy, takie jak: rosnący wskaźnik scholaryzacji wśród pol-

4 Chciałabym jednak zwrócić uwagę na fakt, że dane Eurostatu dotyczą wszystkich osób w określonym wieku, mieszkających z rodzicami, bez informacji o stanie cywilnym. Zakładam zatem - że w przeciwieństwie do prowadzonych przeze mnie badań w 2010 roku (dotyczących tylko osób stanu wolnego) - Eurostat podaje zbiorcze dane dla osób stanu wolnego, osób rozwiedzionych, żonatych/ zamężnych, na co w tym miejscu zwracam uwagę Czytelnika. 
skiej młodzieży, późne wchodzenie na rynek pracy, kryzys małżeństwa, spadek urodzeń, wzrost kohabitacji i inne, które - wzorem krajów Europy Zachodniej i Ameryki Północnej - sprzyjają odraczaniu samodzielności i opóźnianiu separacji od rodziny pochodzenia ${ }^{5}$. Warto w tym miejscu podkreślić, że zmiany dotyczące moratorium, które $\mathrm{w}$ dorobku literatury zachodniej obserwowano kilkadziesiąt lat w postępie ewolucyjnym, w Polsce dokonały się w ciągu ćwierćwiecza.

W symbolicznym roku 1989 Polska weszła na drogę społeczno-ustrojowej transformacji, polegającej na przechodzeniu od społeczeństwa realnego socjalizmu (zamkniętego, ograniczonego, sterowanego) do społeczeństwa kapitalistycznego (wolnorynkowego, otwartego). Ten okres burzliwych przemian politycznych, gospodarczych oraz społeczno-kulturowych - co oczywiste $z$ różnym natężeniem i na różnych płaszczyznach oddziaływał na wybory młodych, ich preferencje i życiowe aspiracje, zanim ukształtował w nich ponowoczesne wzorce. Rebus sic statntibus, można przypuszczać, że wchodzenie w dorosłość miało również różne oblicza sprzęgnięte z możliwościami, jakie stwarzał system społeczny w rozmaitych fazach adaptacyjnych (i rodzinny kapitał).

Zdaniem Zbigniewa Tyszki okres transformacji dzieli się na trzy fazy, które ukazują kolejne przeobrażenia polskich rodzin [Tyszka 2001: 16-24]. I choć przedmiotem mojego zainteresowania nie są w tym momencie przemiany rodziny jako takiej, to odnajduję w tych fazach zróżnicowane podejścia i strategie związane w wkraczaniem młodych w dorosłość. Dzieje się tak między innymi dlatego, że życie jednostki jest wpisane w historię życia rodzinnego i podlega tym procesom makrospołecznym co ona. Wyróżnione trzy etapy transformacji: (1) zaczyna się w drugiej połowie roku 89. i kończy w połowie lat dziewięćdziesiątych; (2) zaczyna się w drugiej połowie lat dziewięćdziesiątych i trwa do końca XX wieku; (3) zaczyna się z początkiem XXI wieku i jest w fazie kontynuacji.

Okres pierwszy zaczyna się w drugiej połowie roku 1989 i kończy w połowie lat dziewięćdziesiątych. Pierwsze lata wolnej Polski wpisują się w „fazę szokową" przeobrażeń społeczeństwa polskiego, które rozpoczęło budowę: gospodarki rynkowej (zastępując dotąd obecną - planową) oraz demokratycznej formy rządzenia i szerzenia demokracji w różnych dziedzinach (zastępując ustrój socjalistyczny), [Tyszka 2001: 20]. Ten trud, z dużym zaangażowaniem podejmują ludzie młodzi (choć nie wszyscy), których dziś nazywa się „aktorami wielkiej zmiany" [Szafraniec 2011: 22].

Mam tu głównie na myśli prace Szlendaka [2010], Slany [2006], Gizy-Poleszczuk [2005], Ziemskiej [2005], Kocik [2002], Adamskiego [2002], Tyszki [2002], Sińczucha [2002], Świdy-Zięby [2000, 1999], Kluzowej [1999]. 
Nowy świat ex definitione stwarzał wiele możliwości dla ówczesnych 20- i 30-latków (a wiec osób urodzonych najpóźniej do połowy lat sześćdziesiątych), podsycał - okiełznane dotąd - życiowe aspiracje i ambicje. Niedostatek i szara rzeczywistość w czasach PRL-u miały być wyparte w szybkim tempie, a ich miejsce zastąpić miał dostatek. Oferta konsumpcjonizmu (życia barwnego, dostatniego i przyjemnego) skutecznie uwiodła młodych, którzy nie chcieli spuścizny po dawnym systemie pełnym niedostatku, problemów i ograniczeń. Dlatego tak chętnie to pokolenie zaczęło nadrabiać edukacyjne niedobory, realizować wizję sukcesu zawodowego, podnosić swój status materialny dążąc do celebracji nowego - zachodniego - stylu życia.

Jednak restrukturyzacja przyniosła pierwsze redukcje zatrudnienia (bezrobocie nie było doświadczane w poprzednim systemie), zrodziła niepewność jutra i pierwsze dywersyfikacje na tle majątkowym. Wzrosła liczba rodzin wykazujących niskie dochody oraz liczba rodzin żyjących w ubóstwie. Badania wykazały również wzrost konfliktów wewnątrzrodzinnych w pierwszej połowie lat dziewięćdziesiątych, co tłumaczy się procesami makrostrukturalnymi zachodzącymi w kraju. Ponadto, zaznaczył się spadek liczby urodzeń (po wielkim boomie demograficznym PRL-u) utrzymujący się do dzisiaj, od 1993 roku liczba małżeństw rozwiązanych zaczęła przewyższać liczbę małżeństw nowo zawartych (głównie z uwagi na zgony) oraz wzrosła liczba rodzin niepełnych [Tyszka 2001: 20].

Mimo zmian, młodzi ludzi, oparci na wzorcach rodem z PRL-u (rodzina na pierwszym miejscu) mieli przed sobą jasne definicje młodości i dorosłości.

Tradycyjnie młodość odnoszona była do osób, które nie osiągnęly jeszcze samodzielności życiowej. (...) Zwieńczenie tej fazy życia, wiązało się z tak konkretnymi wydarzeniami i sytuacjami życiowymi, jak podjęcie pracy, zawarcie małżeństwa, założenie rodziny czy samodzielnego gospodarstwa domowego. Dorosłość była rozpoznawalna po osiągnięciu pełnej stabilizacji życiowej, co zazwyczaj było możliwe mniej więcej w wieku 20 lat. Przejście z fazy młodości (oznaczającej status osoby zależnej, nie traktowanej poważnie i nie mogącej decydować o sobie) do dorosłości (oznaczającej status pełnoprawnego członka społeczeństwa, mogącego samodzielnie decydować o własnym życiu) ma bardzo duże subiektywne znaczenie dla ludzi młodych - daje poczucie niezależności i autonomii. Pozwala być sobą i realizować własną koncepcję życia, bez oglądania się na opinię tych, od których się było zależnym [Szafraniec 2011:37-38].

W tym kontekście odraczanie wyprowadzki z rodzinnego domu opóźniało start w dorosłe życie, a tym samym odraczało osiągnięcie dorosłości. Gniazdowanie dotyczyło nielicznych i z pewnością nie było społecznie akceptowane. 
Okres drugi zamyka się z końcem lat dziewięćdziesiątych. Na ten czas przypada młodość ludzi, których Witold Wrzesień określa „Dziećmi Transformacji” i „Maruderami Końca Wieku” [Wrzesień 2001: 248-249]. Urodzeni między 1972 a 1982, choć wewnętrznie zróżnicowani, to jednak żyjący w podobnym tyglu przemian. Ożywienie gospodarcze, napływ kapitału zagranicznego stymulującego nowe inwestycje i wymuszającego szybką modernizację kraju, postęp technologiczny i telekomunikacyjny, spadek bezrobocia, którego apogeum przypada na 1994, z późniejszą tendencją spadkową [Tyszka 2001 : 20] rozbudziły na niespotykaną dotąd skalę aspiracje edukacyjne i statusowe młodych Polaków, które miały być realizowane głównie dzięki nauce. Aspiracje edukacyjne zostały zagospodarowane przez ekspresowo rozwijający się system szkolnictwa wyższego („eksplozja systemu edukacyjnego”), który w sposób mniej lub bardziej udany pogodził dwie siły: rosnący apetyt na dyplom magistra lub szkoły średniej z - wchodzącym na rynek edukacyjny - wyżem demograficznym. Socjologowie zwracają uwagę, że choć nie nastąpiły znaczące przetasowania w orientacjach życiowych i postawach tego pokolenia młodych w porównaniu z młodymi z pierwszego okresu transformacji, to jednak uzewnętrzniły się pewne różnice, takie jak: naturalne oswojenie $\mathrm{z}$ transformacyjną rzeczywistością, większa ekspansywność życiowa, silniejszy pragmatyzm i bardziej konsumpcyjne nastawienie do życia [Szafraniec 2011: 16]. Często dla zobrazowania ich życiowych orientacji przywoływano obraz „pokolenia X”. Z wiarą w sukces zawodowy coraz częściej poważnie inwestujący w swoją przyszłość, coraz liczniej sięgali po dyplom wyższej uczelni, widząc w nim warunek konieczny dobrego startu w dorosłe życie.

Podobnie jak w przypadku poprzedniego pokolenia, dorosłość analizowali przez wystąpienie zdarzeń należących do tak zwanej wielkiej czwórki, czyli zakończenie edukacji/ szkoły, opuszczenie domu rodzinnego, podjęcie pracy zawodowej, małżeństwo (względnie wejście w związek). Jedyną kwestią, która znacząco różnicowała oba podejścia był czas, w którym owe zdarzenia miały wystąpić. Zważywszy na rosnący w tej fazie transformacji odsetek osób młodych decydujących się na studia/ naukę, jak również rosnący odsetek osób planujących swoją karierę zawodową i inwestujących w rozwój zawodowy, „osiągnięcie” wielkiej czwórki zostało znacząco odroczone w czasie. Nadal jednak akcentowano linearność przejść, następstwo kroków i wyraźny ich kierunek (zmierzający do założenia rodziny). Odraczanie wyprowadzki od opiekunów stawało się coraz częstszym procederem i wynikało przede wszystkim z wydłużenia okresu edukacji młodych.

Warto też zauważyć, za Krystyną Szafraniec, iż 
na początku lat 90. wydawało się, że procesy transformacji systemowej otworzyły nowe szerokie możliwości awansu społecznego. W końcu lat 90. wiele wskazywało na to, że te same procesy wytworzyły nowe podziały społeczne, z silną tendencją do petryfikacji poprzez mechanizmy reprodukcji pokoleniowej [Szafraniec 2001: 27].

Postępowała dywersyfikacja statusu społecznego i materialnego społeczeństwa, której młodzi byli obserwatorami.

Ostatni okres - okres trzeci, będący w stadium kontynuacji w latach 2000-2004, kiedy to Polska zyskała status członka Unii Europejskiej. Od tego czasu nasilał się stan rozbieżności między oczekiwaniami większości Polaków dotyczącymi warunków życia ich rodzin a mało satysfakcjonującą kondycją. Pogłębiało się rozwarstwienie ekonomiczne społeczeństwa, które coraz częściej budziło

masowy sprzeciw ludności, szczególnie tej, która znalazła się na najniższych szczeblach materialnej egzystencji, nie dostrzegając zarazem możliwości awansu społecznego i ekonomicznego. Wzory wyniesione z epoki generowały - przynajmniej u części tych ludzi - postawy roszczeniowe [Tyszka 2001: 21].

W odpowiedzi na pogarszające się warunki życia, niepewność zatrudnienia, trudny rynek pracy spadła liczba urodzeń. Zwiększył się odsetek rozwodów, spadła liczba zawieranych małżeństw, wzrosła liczba rodzin niepełnych oraz liczba kohabitacji. Coraz częściej młodzi wybierali alternatywne wobec małżeństwa formy życia rodzinnego, w tym również życie w samotności. Na tym etapie transformacji młodość przeżywały i przeżywają pokolenia, które urodziły się w latach osiemdziesiątych oraz takie, które urodziły się już w wolnej Polsce, czyli po 1989 roku życia. Jednak znamienne dla nich jest to, że wychowani są w kulturze konsumpcji i z orientacją „na mieć” nie zaś „być”. Jako dzieci przyglądali się zapracowanym, skoncentrowanym na dorobku rodzicom. Oni też dziś koncentrują się wokół wartości materialnych, z tą różnicą, że - jak podkreśla Hanna Świda-Ziemba - dla nich jest to świat zastany, constans, a nie (jak w przypadku rodziców) potwierdzenie statusu i nagroda za lata niedoborów i wyrzeczeń [Świda-Ziemba 2005]. Nie ulega więc wątpliwości, że w przypadku młodych, „,socjalizacja do świata konsumpcji miała swe pierwotne źródło w rodzinie" [Szafraniec 2011: 31]. I między innymi z tej przyczyny rośnie frustracja młodego pokolenia tej fazy transformacji, które konfrontuje dziś swoje rozbudzone ambicje z ograniczeniami własnej (nieustabilizowanej) pozycji i z ograniczeniami systemu. Trudny rynek pracy (silna konkurencja - wejście wyżu demograficznego na rynek pracy/ „eksplozja rynku pracy”, zmniejszająca się w dobie kryzysu podaż miejsc pracy w stosunku do popytu, niedopasowa- 
nie profilu absolwentów do profilu poszukiwanych przez pracodawców pracowników, proponowane formy prowizorycznego zatrudnienia, niskie zarobki) skutecznie zniechęcają młodych do brania życia we własne ręce. Coraz liczniejsze rzesze młodych sięgają $\mathrm{w}$ tej sytuacji do najbardziej racjonalnej strategii, pozostając w systemie edukacji i opóźniając wchodzenie na rynek pracy [Szafraniec 2011: 30] lub emigrując z paszportem Unii Europejskiej. Dzisiejszy świat, pełen ryzyka z nim związanego, wymaga od młodych szczególnej otwartości i refleksyjności oraz aktywnej postawy w planowaniu własnej, zindywidualizowanej biografii (individual life planning). Tego wyzwania nie są w stanie podjąć wszyscy, „wielu z nich nie radzi sobie z nadmiernymi wymogami społeczeństwa, z kulturową presją osiągania sukcesu, z nieczytelnością społecznych norm, brakiem zainteresowania ze strony dorosłych, osłabieniem więzi rodzinnych czy balastem problemów własnych rodziców" [Szafraniec 2011: 29-30]. Stąd coraz częściej w trajektoriach losów młodych ludzi obserwuje się wycofanie, odraczanie w czasie decyzji przejścia w dorosłość lub nawet rezygnację $\mathrm{z}$ bycia dorosłym (za cenę spokoju i niepodejmowania ryzyka). W tej sytuacji gniazdowanie zyskuje na popularności, jednocześnie traci na znaczeniu tak zwane wielka czwórka, która do tej pory nie tylko charakteryzowała większość biografii młodych, ile kreśliła ramy dorosłości. Zdaniem Krystyny Szafraniec, współczesne młode pokolenie doświadcza „rozczarowania dorosłością, która nieodwołanie zmusza do podjęcia wiążących decyzji życiowych. Poczucie, że nie można popełnić błędu, wywołuje strach przed porażką (która może okazać się porażką „totalną”) i niechęć do podejmowania ważnych decyzji życiowych. Dom rodzinny staje się gwarantem bezpieczeństwa i formą azylu zdejmującą część odpowiedzialności za własne życie. Ciągłe porównywanie się z równolatkami, którzy już podjęli zobowiązania przypisane dorosłości, założyli rodzinę i rozpoczęli karierę zawodową, czyni ich życie jeszcze trudniejszym. Niepewność przyszłości i wrażenie niegościnnej teraźniejszości skłaniają do budowania strategii życiowych o moratoryjnym (odraczającym i ucieczkowym) charakterze - w stronę rozwiązań prowizorycznych, tymczasowych lub w stronę samotności" [Szafraniec 2011: 38-39].

I choć przedstawione okresy opisują typy idealne „strategii moratoryjnych”, to nie sposób nie zauważyć, że każda wymieniona faza jest mocno sprzęgnięta z możliwościami i kondycją systemu społecznego, w ramach którego młodzi ludzie dorastają i w ramach którego wchodzą w dorosłe życie. W sytuacji, gdy możliwości te są ograniczone, wchodzenie w dorosłość chętniej jest odraczana.

Według propozycji Krystyny Slany - badając dziś gniazdowników w polskich warunkach - szczególnym zainteresowaniem należy objąć osoby „(...) 
pomiędzy zakończeniem procesu edukacji na poziomie wyższym, gwarantującej podjęcie wysoko kwalifikowanej pracy i oferującej możliwości samorealizacji, a głównym etapem (według tradycyjnych ideologii) formowania rodziny" [Slana 2006: 19], czyli między 25 a 34 rokiem życia, ponieważ ten wiek jest znaczący dla tworzenia nowej rodziny i prokreacji [por. Goldenberg, Goldenberg 2006]. Powyższa perspektywa jest szczególnie istotna z punktu widzenia przyczyn, dla których młodzi mieszkają z opiekunami pod jednym dachem. Istnieje bowiem duże prawdopodobieństwo, że w grupie gniazdowników w wieku od 18 do 24 roku życia, przeważać będzie motyw wydłużającej się edukacji, którą w polskich warunkach młodzi najczęściej kończą w wieku 24 lat. Ciekawe zatem wydaje się rozpoznanie tych przyczyn gniazdowania, które wykraczają poza sformułowania „bo studiuje”, „bo jeszcze uczy się”. Stąd w swoich badaniach koncentruję się na osobach w wieku od 25 do 34 roku życia.

Ponieważ można wyróżnić kilka modeli, w których dorosłe dzieci mieszkają ze swoimi rodzicami (gniazdownicy stanu wolnego, gniazdownicy w związkach, którzy wprowadzili pod dach rodzinny swojego partnera/ partnerkę, gniazdownicy po rozwodzie), w swoich badaniach ograniczę się do jednego typu tak, by precyzyjniej wypowiadać się o powodach gniazdowania. W swojej pracy przyjmuję perspektywę [za: Boyd, Norris 1999], która gniazdownikami traktuje osoby dorosłe stanu wolnego (niezamężne, nieżonate), a więc takie, które nie przystąpiły do etapu tworzenia własnej rodziny (przez wybór życiowego partnera i/lub zrodzone potomstwo).

\section{Młodzi „pod lupą”. Charakterystyka osób stanu wolnego między} 25 a 34 rokiem mieszkających $\mathrm{z}$ rodzicami pod jednym dachem

Kim są osoby, które ex definitione mają za sobą wiek edukacji na wyższym poziomie? Są na etapie największej zawodowej aktywności i jednocześnie mają u boku rodziców w wieku produkcyjnym (niewymagających stałej opieki i pomocy)?

Wspomniana kategoria wiekowa (25-34) jest również podmiotem zainteresowania europejskich badań nad polskimi gniazdownikami (w ramach projektu EU-SILC - European Union Statistics on Income and Living Conditions $)^{6}$, których wyniki postaram się zaprezentować na tle pomiarów w innych krajach.

6 W projekcie EU-SILC obserwacji podlegają dwie kategorie wiekowe osób mieszkających z rodzicami: osoby w wieku 18-24 lata oraz 25-34 (możliwe są również zbiorcze zestawienia dla obu wspomnianych kategorii). 
Polska została objęta przedsięwzięciem od 2005 roku, czyli w momencie, kiedy zrealizowałam pierwsze badanie dotyczące gniazdowników w ramach projektu „Aktualne problemy i wydarzenia” w CBOS-u. Ostatnie dostępne wyniki z EU-SILC pochodzą z 2012 roku, wiec są nieco bardziej aktualne od zrealizowanych przeze mnie w 2010 roku. Co jednak istotne, w pomiarach EU-SILC nie ma wiedzy na temat stanu cywilnego badanej grupy gniazdowników. Należy zatem mieć na uwadze fakt, że w projekcie europejskim, w ramach gniazdowników, znajdują się osoby młode mieszkające z rodzicami bez względu na ich stan cywilny. W moich badaniach występują tylko osoby stanu wolnego, które nie zawarły związku małżeńskiego.

Pragnę jednocześnie podkreślić, że dane z krajów Unii Europejskiej traktuję tylko jako tło dla odsetka odraczających separacji od rodziny pochodzenia w Polsce. Nie jest moim celem analiza uwarunkowań społecznych, kulturowych i gospodarczych przedstawianych krajów, na co w tym miejscu zwracam uwagę Czytelnika.

Jak wynika z danych Eurostatu, w 2012 roku w Polsce odsetek osób mieszkających przynajmniej z jednym z rodziców w stosunku do ogółu populacji osób w wieku 25-34 wyniósł 43,4\%. Odsetek osób mieszkających z opiekunami pod jednym dachem w naszym kraju w tej grupie wiekowej jest wyższy o 13 punktów procentowych niż ogólnie w 27 krajach Unii Europejskiej (30,4\%). Polska plasuje się z podanym wynikiem obok krajów takich, jak Słowenia $(43,5 \%)$, Rumunia (44,4\%), Portugalia (44,5\%) i Włochy (46,6\%). Hiszpania - o której dużo się pisze i mówi w kontekście wysokiego bezrobocia - ma mniej osób gniazdujących, bo 37,2\%. Dla porównania, najwyższy, odsetek takich osób odnotowano w nowych państwach członkowskich i państwach Europy Południowej: Chorwacji (58,6\%), Słowacji (56,6\%), Bułgarii (52,8\%) i Grecji $(51,6 \%)$. Najmniej natomiast w krajach Europy Północnej: w Danii (1,8\%), Finlandii (4,0\%), Szwecji $(4,1 \%)$ i Norwegii $(4,2 \%)$.

W stosunku do 2005 roku w Polsce zwiększył się odsetek osób w wieku 2534 mieszkających z rodzicami z 36,4\% do 40,7\% (o 4,3 punktu procentowego dalej pp) w 2010 - i dalej - do 43,4\% w roku 2012 (o 7 pp w porównaniu z 2005 rokiem).

Dla przypomnienia, podczas prowadzonych przeze mnie badań w CBOS-ie (2005) oraz w TNS OBOP (2010) odnotowałam w Polsce nieznaczną (mieszczącą się w granicach błędu) tendencję wzrostową tej kategorii wiekowej w ogóle badanych przeze mnie osób stanu wolnego mieszkających z opiekunami (z 29\% do $32 \%)$.

Niewielka tendencja wzrostowa obserwowana jest również w 27 krajach Unii Europejskiej. Wzrost odsetka osób mieszkających pod jednym dachem 
z opiekunami odnotowano między 2005 a 2012 rokiem na poziomie 3,2 pp (na marginesie między 2005 a 2010 poziom gniazdujących w wieku 25-34 utrzymywał się w skali europejskiej na tym samym poziomie - zmiana in plus o 0,2 pp).

Największy wzrost w porównaniu do pomiaru z 2005 roku odnotowano na Słowacji (o 11,9 pp), Bułgarii (o 11,3 pp) i na Węgrzech (10,8 pp). Polska ze swoim wynikiem - wzrost odsetka gniazdujących w wieku 25-34 o 7 pp - na szóstej pozycji od góry, „deklasując” tym samym osławione gniazdownikami państwa takie, jak Włochy, Portugalia czy Grecja, nie wspominając już o Hiszpanii, która w badanym okresie odnotowała nieznaczny spadek osób mieszkających z rodzicami. Największy spadek odsetka odnotowano w Estonii (o 7,1 pp), Słowenii (o 6,1 pp) oraz w Niemczech (o 4,4 pp).

Według danych Eurostatu, w Polsce mężczyźni w wieku 25-34 częściej niż kobiety mieszkają z rodzicami pod jednym dachem. Wśród mężczyzn w 2012 odsetek wzrósł o 6,6 pp w porównaniu z rokiem 2005, wśród kobiet - o 7,5 pp.

$\mathrm{W}$ prowadzonym przeze mnie badaniu w 2005 roku w ramach „Aktualne problemy i wydarzenia" w CBOS-ie nie badaliśmy płci pełnoletnich stanu wolnego mieszkających z rodzicami pod jednym dachem, stąd nie mam możliwości, by odnieść się do ewentualnych zmian w czasie.

Tendencja wzrostową, zarówno w grupie mężczyzn, jak i kobiet, charakteryzuje gniazdowników europejskich - na przestrzeni 7 lat w Unii Europejskiej nastąpił wzrost odsetka mężczyzn w podanej grupie wiekowej o 3,8 pp, zaś wśród kobiet o 1,5 pp.

Największy wzrost odsetka mężczyzn mieszkających z rodzicami do ogółu w kategorii wieku 25-34 odnotowano w Bułgarii (o 14,5 pp), Słowacji (o 13,7 pp), Węgrzech (o 12 pp). Polska pod względem wzrostu znajduje się na 7 pozycji (spośród 27 krajów UE), wyprzedzając wzrostem wyniki Portugalii, Włoch i Grecji. Największy spadek odsetka mężczyzn pozostających w rodzinnym gnieździe do ogółu w kategorii odnotowano w Estonii (o 8,5 pp), Słowenii (o 7,9 pp), Niemczech (o 6,3 pp) i Finlandii (o 3,7 pp).

Największy wzrost odsetka kobiet mieszkających z rodzicami do ogółu w kategorii wieku 25-34 odnotowano na Malcie (o 12,9 pp), w Grecji i na Węgrzech (o 9,7 pp), na Słowacji (o 9 pp) i w Polsce. Największy spadek odsetka kobiet pozostających w rodzinnym gnieździe w porównaniu do ogółu w kategorii odnotowano w Estonii (o 5,8 pp), Słowenii (o 4,6 pp), Łotwie (o 3,6 pp).

Jaki jest status społeczno-zawodowy polskich gniazdowników? Jakie mają wykształcenie? Czy pracują zawodowo? Jaka jest ich sytuacja finansowa?

Jak wynika z badania zrealizowanego w 2010 roku, w Polsce co druga osoba (52\%) stanu wolnego w wieku 25-34 lata mieszkająca $\mathrm{z}$ rodzicami ma średnie 
wykształcenie lub pomaturalne. Co trzecia (36\%) posiada wykształcenie wyższe lub licencjat.

Trzy czwarte (72\%) pełnoletnich stanu wolnego w wieku 25-34 lata mieszka z rodzicami, mimo iż pracuje. Co dziesiąty (11\%) jeszcze uczy się lub studiuje. Bezrobotni stanowią $8 \%$, pozostali $-6 \%$ - to renciści lub niepracujący z innych powodów.

W porównaniu do badania, które realizowałam w CBOS-ie z 2005 roku wyraźnie wzrosła grupa osób pracujących (o 10 pp), zaś zmalała grupa osób bezrobotnych (o $12 \mathrm{pp})$.

Podobne trendy odnajdujemy w danych Eurostatu, z których wynika, że w 2012 roku mieszkający w rodzinnym gnieździe pracujący na pełny etat stanowią 68\% (na niepełny - 5\%) populacji Polaków w wieku między 25 a 34 rokiem życia i radzą sobie z pracą lepiej niż przeciętny Europejczyk (pracujących w wieku 25-34, którzy mieszkają $\mathrm{z}$ rodzicami pod jednym dachem w 27 krajach członkowskich UE jest 56\%). Warto jednak zauważyć, że przeciętny Europejczyk ma częściej stałą pracę niż Polak (różnica 14 punktów procentowych w 2012 roku). Mimo to, pamiętajmy, że tak większość Polaków, jak i większość Europejczyków w wieku 25-34 mieszkających z rodzicami pod jednym dachem ma dziś stałą pracę.

Dane na rok 2012 dla Polski (dotyczące zatrudnienia na pełny etat) są zbliżone do sytuacji sprzed dwóch lat (w 2010 - 69\%), różnicę widać jednak z pomiarem z 2005 roku, ponieważ w omawianej grupie było wówczas wyraźnie mniej osób pracujących na pełny etat (58\%).

Według danych Eurostatu z 2012 roku w Polsce 14\% osób w wieku 25-34 to mieszkający z rodzicami bezrobotni, mniej ich w Polsce (o 4 punkty procentowe) niż średnio w 27 krajach Unii Europejskiej. Stosunkowo mniej mamy również w tej grupie studentów, bowiem w Polsce zaledwie 4\%, średnio w 27 krajach UE - 14\%.

Na tle mieszkających z rodzicami z krajów Unii Europejskiej widać, że Polacy w tej grupie stosunkowo częściej są osobami pracującymi, rzadziej natomiast bezrobotnymi czy studentami.

W swoim badaniu w 2010 roku pytałam dodatkowo o finansową (nie)zależność pełnoletnich, którzy mieszkają z rodzicami pod jednym dachem. Nie zawsze bowiem podjęcie pracy zarobkowej przynosi dochody pozwalające na usamodzielnienie się. Skromna pensja stanowić może czynnik determinujący wspólne zamieszkiwanie. W Europie dobrze znany jest problem niskich wynagrodzeń, jakie otrzymują młodzi ludzie oraz warunków pracy na tymczasowych warunkach, niepozwalających na przykład na zaciągnięcie kredytu (mam 
tu na myśli sytuację młodych Włochów, nazywanych „pokoleniem 1000 euro” oraz młodych Greków, nazywanych „pokoleniem 600 euro”).

W Polsce najliczniejszą grupę spośród osób w wieku 25-34, które nie opuściły jeszcze domowego gniazda stanowią osoby całkowicie finansowo niezależne od swoich opiekunów i stanowią ponad połowę całej grupy (55\%). Co czwarta (24\%) osoba jest zależna po części; 18\% gniazdujących w wieku 25-34 jest całkowicie zależnych finansowo od swoich opiekunów.

Jak wynika z przytoczonych wyżej danych Eurostatu, Polacy nieco rzadziej niż ogół młodych Europejczyków mają stałą pracę (choć posiadający stałą pracę stanowią większość tak w Polsce, jak w krajach europejskich ogółem), to już znacznie częściej niż Europejczycy posiadają pracę w pełnym wymiarze godzin (cały etat).

Jak wynika z badań, grupa osób mieszkających z rodzicami pod jednym dachem, w wieku między 25 a 34 rokiem życia wymyka się prostym schematom i opisom. Nie są to bowiem osoby, które głównie uczą się lub studiują i z tego tytułu pozostają w rodzinnym gnieździe. Gros z nich to osoby pracujące (posiadające stałe zatrudnienie, pełny etat) i finansowo w pełni niezależne. W tym miejscu trafne wydaje się zwrócenie szczególnej uwagi na tę kategorię wiekową, tak w analizach ilościowych, jak i w realizowanych na tej grupie badaniach jakościowych. Nieuchronnie nasuwa się zatem pytanie o powody, dla których nie odcinają pępowiny od rodziny pochodzenia.

\section{Powody mieszkania z rodzicami pod jednym dachem}

Respondentów, w których rodzinach pełnoletnie dzieci stanu wolnego nadal mieszkają z rodzicami pod jednym dachem, poprosiliśmy o samodzielne wskazanie przyczyn tego stanu.

Kwestia określenia powodów jest niezwykle istotna z punktu widzenia definicji gniazdowania i definicji gniazdownika. Przypomnę tylko, że odcięcie pępowiny od rodziny pochodzenia jest wpisane w rozwój człowieka zdrowego. W przypadkach niedołężności osób stanu wolnego, naturalną koleją rzeczy jest wspomaganie ich i opieka oferowana przez członków rodziny. Poważnym nadużyciem byłoby żądanie usamodzielnienia i wyprowadzki od rodziny w stosunku do osób bardzo chorych. Ergo, taka forma relacji i koegzystencji rodzic-dziecko, nie wpisuje się w "gniazdowanie”. Kolejną sytuacją, wymykającą się spod skrzydeł definicji jest wspólne zamieszkiwanie z powodu pomocy, jaką dorosłe dzieci oferują swoim rodzicom - nie zaś na odwrót. Exempli causa, 
kiedy opiekują się chorymi rodzicami, bo ci ostatni, nie byliby w stanie zadbać o siebie i - co oczywiste - utrzymać się, lub kiedy zapraszają ich pod dach swojego domu, dając wikt i opierunek. Problem zgoła odmienny, ale również pozostający poza obszarem mojego zainteresowania - to pozostawanie w rodzinnym gnieździe, które jest następstwem tradycji i przekazania gospodarstwa rolnego „z ojca na syna”.

Jak wynika z badań prowadzonych w 2010 i 2005 roku, każdy z omówionych powyżej przypadków jest śladowy (od 0 do 3\%, w granicy błędu statystycznego), co oznacza, że nie redukuje próby w zauważalny sposób. Innymi słowy, powszechnie przywoływane powody pozostawania osób pod dachem rodziców są zgoła odmienne od wyżej przytoczonych. Dlatego też, uważam za uprawnione nazywanie Polaków stanu wolnego mieszkających z rodzicami pod jednym dachem gniazdownikami, ponieważ powody, dla których zwlekają z odcięciem pępowiny są zgoła odmienne od przytoczonych.

Jak wynika z badań ilościowych, najliczniejsza grupa wskazuje jako powody czynniki ekonomiczne (brak mieszkania - 31\%, brak pieniędzy - 9\%, brak pracy - 5\%, oszczędność - 5\%). Samotność (brak partnerki/ partnera)i niemożność założenia rodziny to powód, dla którego odracza odcięcie pępowiny co piąty (21\%) gniazdujący w wieku 25-34 lata. Wygoda (12\%), ale także nauka (w szkole średniej lub wyższej) i związane z nią obowiązki to powód wyjaśniający brak możliwości lokalowego usamodzielnienia się dla 12\% (tabela 1).

Tabela 1. Powody mieszkania z rodzicami osób 25-34 stanu wolnego

\begin{tabular}{|l|c|c|}
\hline \multicolumn{1}{|c|}{ Wyszczególnienie } & $\begin{array}{c}2010, \mathrm{~N}=182 \\
\text { TNS OBOP }\end{array}$ & $\begin{array}{c}\text { 2005, N=218 } \\
\text { CBOS }\end{array}$ \\
\cline { 2 - 3 } & \multicolumn{2}{|c|}{$[\%]$} \\
\hline Brak mieszkania & 28 & 30 \\
\hline $\begin{array}{l}\text { Osoba nie założyła własnej rodziny, jest to osoba } \\
\text { samotna }\end{array}$ & $19^{*}$ & $9^{*}$ \\
\hline Wygoda & 12 & 14 \\
\hline Kontynuowanie nauki (edukacja, szkolenie się) & 10 & 12 \\
\hline $\begin{array}{l}\text { Brak pieniędzy, dochody nie pozwalają się usamo- } \\
\text { dzielnić (jest na utrzymaniu rodziców) }\end{array}$ & $8^{*}$ & $36^{*}$ \\
\hline Brak pracy & $5^{*}$ & $16^{*}$ \\
\hline Dobre warunki lokalowe w domu rodzinnym & 5 & 6 \\
\hline $\begin{array}{l}\text { Pomoc rodzicom (również pomoc przy gospodar- } \\
\text { stwie domowym) }\end{array}$ & 5 & 2 \\
\hline
\end{tabular}




\begin{tabular}{|l|c|c|}
\hline Ta osoba wymaga opieki (osoba niepełnosprawna) & 4 & 1 \\
\hline $\begin{array}{l}\text { Niższe koszty utrzymania, razem łatwiej się } \\
\text { utrzymać }\end{array}$ & 2 & $\begin{array}{c}\text { brak kodu } \\
\text { w } 2005\end{array}$ \\
\hline $\begin{array}{l}\text { Poczucie więzi, zależności emocjonalne; chęć wspól- } \\
\text { nego mieszkania }\end{array}$ & 1 & 4 \\
\hline Opieka nad członkiem rodziny & 0 & 1 \\
\hline Mieszkanie jako spadek & 0 & 4 \\
\hline To rodzice mieszkają u respondenta & 0 & 0 \\
\hline
\end{tabular}

Uwagi: Pominięto odpowiedzi „trudno powiedzieć”. Procenty nie sumują się do 100, ponieważ respondent mógł wymienić kilka powodów, dla których pełnoletnia osoba stanu wolnego mieszka z rodzicami. Sortowano malejąco według częstości wskazań dla ogółu badanych w 2010 .

* Podstawa: osoby posiadające dorosłe dzieci mieszkające z rodzicami w rodzinie

* wynik istotny statystycznie na poziomie 0,05 .

Źródło: opracowanie własne na podstawie danych z badania TNS OBOP [2010] i CBOS [2005]

W porównaniu z poprzednim pomiarem z 2005 roku można zaobserwować istotne zmiany powodów, dla których młodzi odraczają separację od rodziny pochodzenia. Znacząco (o 22 pp) spadł odsetek gniazdujących z powodu braku pieniędzy, czy braku pracy (spadek o $8 \mathrm{pp}$ ). Wzrósł natomiast odsetek skarżących się na brak mieszkania (o 8 pp) i samotność, która „nie pozwala” założyć rodziny i wyprowadzić się (wzrost o 8 pp w 2010 roku).

„Brak mieszkania” jest najczęściej podnoszony wśród powodów, dla których młodzi dorośli pozostają w rodzinnym gnieździe. Trudno jednak nie ulec przekonaniu, że jest to forma racjonalizacji rzeczywistych powodów (podobnie jak inne podane ad hoc powody). Odpowiedź „brak mieszkania”, nasuwa serię kolejnych pytań, a może tylko jedno, choć zadawane kilkakrotnie: „dlaczego tak jest?”. „Dlaczego nie masz mieszkania? „Dlaczego nie stać cię na zakup mieszkania? „Dlaczego nie masz pieniędzy?” „Dlaczego nie masz pracy?” „Dlaczego nie możesz znaleźć zatrudnienia?”. Ta seria pytań, może pomóc wyjść z prostych schematów, racjonalnych powodów i pozwali poznać więcej.

Pytania otwarte $\mathrm{w}$ badaniach ilościowych, choć zdradzają wiele i są niekwestionowanym źródłem informacji, to w moim przekonaniu, wymagają pogłębienia. 


\section{Próba głębszego wniknięcia w rzeczywistość społeczną. Wyniki badania jakościowego}

W badaniu jakościowym, zanim zostały zadane pytania o powody zamieszkiwania $z$ rodzicami, pytałam o wyzwania, cele życiowe i aspiracje. Zwraca uwagę, fakt, że powody deklarowane różniły się od aspiracji i dążeń gniazdowników.

Z palety deklarowanych powodów, dla których młodzi Polacy ${ }^{7}$ mieszkają z rodzicami pod jednym dachem, oni sami silnie akcentują brak własnego mieszkania ${ }^{8}$. Ten aspekt nie tylko przywołują najczęściej jako pierwszy (top of mind) albo jedyny, ale też poświęcają mu najwięcej uwagi. Zdaniem gniazdowników, u podłoża tego stanu rzeczy stoją zbyt wysokie ceny mieszkań na rynku (kwestia podnoszona jest przez pytanych niezależnie od regionu zamieszkania). Niepracujący - w badanej grupie - rozwiązanie problemu widzą w "znalezieniu dobrej pracy”, a więc takiej, której wynagrodzenie pozwoli pokryć wydatki na osobiste potrzeby, a przy tym zaoszczędzić. Z kolei osoby pracujące kładą nacisk na konieczność zgromadzenia oszczędności wystarczających na zakup mieszkania.

Warto jednak zauważyć, że w kontekście „braku własnego mieszkania”, gniazdownicy często deklarują swój sceptycyzm wobec zaciągania kredytu hipotecznego w banku lub sprzeciw wobec wynajmu mieszkania czy pokoju lokatorskiego.

Sceptycyzm pytanych do zakupu mieszkania z udziałem kredytu wynika głównie $\mathrm{z}$ niepewności, a w konsekwencji niechęci do podjęcia ryzykownego, finansowego zobowiązania na lata. Należy jednak zauważyć, że ta postawa ma swoją amplitudę. Szczególnie silnie akcentują swój sceptycyzm - a może nawet niechęć - wobec kredytowej formy zakupu mieszkania osoby, które w dniu badania deklarowały brak życiowego partnera (partnerki).

Nie można jednak wykluczyć, że zmiana życiowych okoliczności (znalezienie tak zwanej „bliskiej osoby”) może wpłynąć na wyrażaną dziś opinię. Do zgłoszenia tej tezy prowadzi mnie postawa badanych pozostających w związkach, którzy są mniej sceptyczni wobec zaciągania kredytów i nie odrzucają tej formy finansowania mieszkania w przyszłości (choć jeszcze dziś od niej stronią). Bez większego wpływu pozostaje fakt posiadania zdolności kredytowej przez badanych w chwili wywiadu.

Wyraźny sprzeciw wśród pracujących gniazdowników budzi natomiast wynajem mieszkania czy pokoju lokatorskiego. Konieczność uzasadnienia tej postawy - ujawniająca się w toku zadawanych przeze mnie pytań szczegółowych

\footnotetext{
Przypominam, że w badaniu jakościowym (IDI) gniazdownicy byli w wieku między 25 a 34 rokiem życia.

8 Odpowiedzi udzielone na pytanie zadane „wprost” o powody, dla których rozmówcy mieszkają z rodzicami.
} 
- często wywoływała irytację badanej osoby. Zdaniem pytanych „oczywistym” powodem gniazdowania jest oszczędność. Wynajem mieszkania lub pokoju lokatorskiego stoi - w ich opinii - w sprzeczności z „racjonalnym” i „zdrowym” zarządzaniem zarobionymi pieniędzmi i „po prostu nie opłaca się”. Należy też zauważyć, że przeznaczenie pieniędzy na wynajem jest w opinii badanych utożsamiane ze stratą (gniazdownicy nie dostrzegają korzyści wynikających z niezależności lokalowej od rodziców).

Kwestia oszczędności ma wiele twarzy i zwykle badani podają dodatkowe okoliczności jej towarzyszące. Zanim jednak przejdę do kompleksowego omówienia problemu, pragnę wspomnieć pokrótce o innym aspekcie, który pojawia się przy okazji wyrażanej przez gniazdowników niechęci do wynajmu. Znacząca w tym względzie jest artykułowana potrzeba wolności, stojąca w sprzeczności z rysowaną postawą rentiera (kontrolującego, narzucającego swoje reguły) czy też innych lokatorów, z którymi trzeba byłoby dzielić mieszkanie.

Chęć zaoszczędzenia to bez wątpienia znaczący - w opinii badanych gniazdowników - powód mieszkania z rodzicami pod jednym dachem. Zasługuje on na osobne potraktowanie nie tylko ad vocem niechęci do wynajmowanego lokalu. Oszczędności, o jakich mówią badani mają na celu poprawę ich sytuacji ekonomicznej, rzadziej jest to forma wsparcia rodziców. W tym ostatnim przypadku pomoc wynika raczej z konieczności (z zaistniałej trudnej sytuacji w gospodarstwie domowym) niż chęci. Gniazdowanie pozwala badanym zaoszczędzić pieniądze po to, by odłożyć je na „czarną godzinę” czy „na inwestycje”.

Badani rzadko (zaledwie dwa przypadki w próbie) zwracają uwagę na fakt, że zaoszczędzone środki pozwalają im na zaspokojenie bieżących potrzeb konsumpcyjnych, kulturalno-oświatowych, realizację własnego hobby. W deklaracjach, powód utrzymania określonego statusu ekonomicznego zostaje przez moich rozmówców niemal niezauważony (to silna opozycja wobec wątków, które pojawiają się przy okazji wydatków respondentów, domowego budżetu i wkładu, jaki badani weń wnoszą).

Bywa jednak, że mieszkanie z rodzicami pod jednym dachem to pomoc, jaką dorosłe dzieci oferują swoim rodzicom (szczególnie tam, gdzie rodzice stracili pracę, są na emeryturze lub rencie).

Kwestię oszczędności potraktowałam jako wartą osobnego omówienia. Tymczasem, ona nigdy nie występowała w wypowiedziach badanych „pojedynczo" („solo”), a tylko w „asyście” innych powodów. Najchętniej towarzyszyły jej:

- relacje i „układy” z rodzicami (w tym pomoc udzielana rodzicom);

- niechęć do samodzielnego zamieszkania (do zamieszkania w pojedynkę). 
Niechęć do samodzielnego mieszkania jest podnoszona przez osoby posiadające partnera/ partnerkę (w kontekście możliwości oszczędzania i dzielenia kosztów). Wyraźnie zaznacza się też kontekst etapu, na jakim znajduje się związek i ewentualnych przyszłych deklaracji. W badanej próbie, mimo dużego udziału osób samotnych (ale też poszukujących partnera/ partnerki), zaledwie jedna osoba wskazała, że obawia się samotności. W deklaracjach tej grupy brak życiowego partnera nie jest powodem, który skłania do mieszkania $\mathrm{z}$ rodzicami. Za to wspomniane osoby chętnie zwracają uwagę na wygodę mieszkania z rodzicami, widzianą głównie przez pryzmat dobrych warunków lokalowych (posiadania własnego pokoju, mieszkania w wolno stojącym domu), rzadziej jako brak domowych obowiązków i przysłowiowy darmowy „wikt i opierunek”. Bywa, że respondenci nie widzą konieczności wyprowadzki, ponieważ większość potrzeb jest w tym układzie (w koegzystencji z rodzicami) zaspokajanych. Do marginalnych powodów - a mimo to obecnych w deklaracjach respondentów - należy zaliczyć kontynuowanie nauki i przyjęty przez respondentkę kodeks moralny oraz niechęć wobec zamieszkania z partnerem przed ślubem.

Opisując powody, dla których gniazdownicy mieszkają z rodzicami pod jednym dachem nie sposób pominąć splotu powodów i wielości pobudek, które skłaniają dorosłych Polaków stanu wolnego do mieszkania z rodzicami. Poza „brakiem mieszkania” wszystkie inne powody występują w konstelacji innych aspektów, co zdradza, jak sądzę, skąplikowaną naturę zjawiska.

Opinie rodziców gniazdowników na temat powodów wspólnego zamieszkiwania są zbieżne z deklaracjami ich dzieci. Opiekunowie - podobnie jak ich dorosłe pociechy - wskazują na brak mieszkania i środków na jego zakup, możliwość oszczędzenia większych pieniędzy we wspólnocie, zwracają uwagę na wygodę dzieci (jednak nieco inaczej rozumianą, głównie jako brak obowiązków i konieczności ponoszenia przez nie opłat), dostrzegają pomoc pociech w trudnej sytuacji rodzinnej, zwracają uwagę na obowiązek nauki na poziomie studiów wyższych.

Nowymi aspektami - w porównaniu z deklaracjami samych gniazdowników - są: przywoływany przez rodziców brak życiowego partnera/ partnerki („nie ma żony, więc mieszka z nami”) oraz niechęć do zaangażowania się w związek $\mathrm{z}$ płcią przeciwną w obawie przed niepowodzeniem, czy też w odpowiedzi na obserwowane „trudne” relacje małżeńskie rodziców (złe stosunki między matką i ojcem).

Ostatnio przytoczone kwestie, mimo że naświetlone przez rodziców, pojawią się ponownie - tym razem w motywach nieuświadomionych lub utajonych - samych gniazdowników. 
Przytoczone deklaratywne powody, dla których badani Polacy stanu wolnego mieszkają z rodzicami pod jednym dachem, prima facie nie odbiegają od tych, które zostały wyłonione $\mathrm{w}$ reprezentatywnych badaniach ilościowych (odpowiedzi na pytanie otwarte - pomiary 2005 CBOS, 2010 TNS OBOP).

Aby poznać kontekst przytoczonych powodów deklaratywnych, oraz by dotrzeć do nieuświadomionych lub utajonych motywów gniazdowania moich bohaterów zaprezentuję ich aspiracje i dążenia.

$\mathrm{W}$ rzeczywistości wyprowadzka $\mathrm{z}$ rodzinnego domu i uniezależnienie od rodziców nie stanowią wyzwaniem dla gniazdowników ${ }^{9}$. Dzieje się tak nie dlatego, że usamodzielnienie jest łatwym przedsięwzięciem, a dlatego, że nie funkcjonuje w świadomości gniazdowników jako stojące dzisiaj przed nimi trudne zadanie. Ten obszar zarezerwowany jest dla zgoła odmiennych treści.

Badani identyfikują wyzwania przede wszystkim z niezaspokojonymi potrzebami. Należą do nich: potrzeba posiadania pracy (wśród osób bezrobotnych), potrzeba podniesienia swoich kwalifikacji (wśród osób o niższym lub niekompletnym wykształceniu), potrzeba posiadania życiowego partnera/ partnerki (wśród osób samotnych), potrzeba akceptacji w grupie rówieśników lub środowisku pracy (szczególnie silna wśród homoseksualistów) oraz potrzeba awansu społecznego (w przypadku osoby z rodziny robotniczej).

Co jednak istotne, wymienione „wyzwania” badani niejednokrotnie zaliczają do sfery osobistych niepowodzeń i życiowych porażek. Takie podejście świadczy o nadaniu wysokiej rangi niezaspokojonej potrzebie (wyzwaniu) z jednej strony, z drugiej zaś przeświadczeniu o trudności jej realizacji. W skrajnych przypadkach wspomniana trudność prowadzi do rezygnacji i wycofania badanych z aktywności w problematycznej sferze życia ( $\mathrm{z}$ uwagi na duże koszty emocjonalne „niepowodzenia” kolejnej podjętej próby oraz lęku przed tym, co nieznane [Horney 1997 : 62]), co ostatecznie przekłada się na niechęć lub nieumiejętność podjęcia innych zadań rozwojowych człowieka wchodzącego w dorosłość.

Nasuwa się też interpretacja, że badani swoje niezaspokojone potrzeby klasyfikują w hierarchii, gdzie zgodnie z sugestią Maslowa dopiero zaspokojenie podstawowej potrzeby, odsłoni inną perspektywę. Niezaspokojenie dzisiaj istniejących „potrzeb - wyzwań" skutecznie przysłania nowe obszary, a zarazem nowe możliwości. Przykładowo, badani, którzy znalezienie partnera trak-

9 Wyprowadzkę z rodzinnego domu i uniezależnienia nie należy traktować $\mathrm{w}$ tym punkcie literalnie, a szeroko. W rozmowach $\mathrm{w}$ tym aspekcie nie tylko nie pojawiają się kwestie wyprowadzki, usamodzielnia, uniezależnienia, ale też rozmówcy nie wymieniają problemów szeroko pojętego „braku mieszkania” (braku możliwości wynajmu i/lub zakupu, drogich cen mieszkań/ najmu) czy nawet możliwości zaoszczędzenia środków na mieszkanie/ wynajem. 
tują jako największe swoje wyzwanie, nie widzą sensu w wyprowadzce. Uznają, że znalezienie „drugiej połówki” za priorytetowe i jedynie potrzebne. Nie podejmują innych kroków. Tymczasem ci sami badani często podkreślają, że mieszkanie z rodzicami ogranicza ich życie towarzyskie („nie mogę zapraszać gości tak, jak bym chciał”, „nie mieszkam tu sama, muszę liczyć się z domownikami, wiadomo"). Skoncentrowani na potrzebie znalezienia partnera, nie widzą innych rozwiązań oraz możliwości, jakie mogłaby otworzyć przed nimi - choćby - wyprowadzka.

Drugim silnym nurtem - obok „wyzwań - potrzeb” - jest sprostanie codziennym obowiązkom, zawodowym lub rodzinnym. Jeśli więc codzienność jest wyzwaniem dla gniazdownika, a w niej sprostanie wymaganiom/ obowiązkom zawodowym czy domowych (jakkolwiek niełatwym i angażującym), trudno się dziwić, że rezygnują z kolejnych kroków, które poszerzyłyby zakres ich odpowiedzialności. W tej grupie gniazdowników silnym motywatorem do pozostawania $\mathrm{w}$ domu rodzinnym jest wygoda wspólnego $\mathrm{z}$ rodzicami zamieszkiwania, o której mówią sami badani, a tu fakt, że nie muszą się troszczyć o codzienny posiłek, pranie i inne „przyziemne” obowiązki. Należy również zauważyć, że dla tych osób praca lub opieka nad chorym ojcem wypełniają całą przestrzeń życiową (motyw, który przewija się w wywiadzie często w różnych kontekstach).

Warto podkreślić, że nie wszyscy badani podjęli temat życiowych wyzwań. Byli i tacy, którzy nie stawiali przed sobą żadnego. Taka postawa szczególnie widoczna była u osób o wyjątkowo niskim poczuciu wpływu na własne życie i własnego sprawstwa (wybór studiów i zawodu - „z przypadku”, niechęć do planowania).

Podsumowując wymienione przez badanych wyzwania, nasuwa się wniosek, że wszystkie można zaliczyć do zadań rozwojowych charakterystycznych dla osób młodych: adolescentów raczej niż dorosłych. Stąd usamodzielnienie widziane przez pryzmat wyprowadzki z rodzinnego domu, wydaje się etapem, na który gniazdownicy jeszcze nie są gotowi.

Chęć wyprowadzki z rodzinnego domu (lub zakupu własnego mieszkania) nieśmiało pojawia się dopiero na etapie marzeń i tylko u nielicznych gniazdowników! Dominujące w tej kategorii jest bezpieczeństwo materialne, o którym rozmówcy mówią wprost, lub do którego zmierzają innymi drogami (na przykład: uprzednim zdobyciem pracy, stabilną sytuacją zawodową czy wygraną w loterii). Marzenie gniazdowników o bezpieczeństwie materialnym jest w istocie marzeniem o finansowym zapleczu, które uchroni ich przed codzienną troską o „wikt i opierunek” i pozwoli realizować siebie (swoje plany, hobby i inne). Co jednak ciekawe, w wypowiedziach respondentów zwraca uwagę nie- 
chęć wobec aktywnego podejmowania życiowych wyzwań („żebym nie musiał się martwić”, „życie bez napięcia czy bez stresu”, „chciałbym być pewny, (...) że nie znajdę się na zakręcie życiowym”, „spokojnie dożyć starości”, „żeby nie było jakichś większych problemów").

Kolejnym marzeniem, silnie akcentowanym przez gniazdowników jest chęć posiadania partnera/ partnerki, chęć posiadania rodziny i dzieci. Warto zwrócić uwagę na fakt, że jest to marzenie o posiadaniu osób bliskich i zaufanych wokół, nie zaś marzenie o miłości (doświadczaniu miłości: dawaniu miłości i byciu obdarowanym). Słowo miłość, zostało wywołane w rozmowach przez gniazdowników zaledwie dwa razy w innej funkcji (w sferze marzeń nie wystąpiło). Chęć posiadania rodziny lub życiowego partnera/ partnerki zajmuje szczególne miejsce w sferze marzeń osób, które nie wyobrażają sobie życia w samotności (choć dziś deklarują się jako osoby samotne), ale też są nieufni w relacjach z otoczeniem (imponuje im szczerość w relacjach, otwartość i umiejętność nawiązywania kontaktów w towarzystwie, bezinteresowna pomoc innym). Można zatem przyjąć, że chęć posiadania rodziny to chęć posiadania osób, na których można polegać. Rodzina innymi słowy, to bezpieczna przystań w opozycji do zewnętrznego świata, któremu nie można zaufać.

Jak wcześniej wspomniałam, chęć zakupu własnego mieszkania i uniezależnienia pojawiła się po raz pierwszy w wywiadzie w sferze marzeń (a powróci w sferze planów na przyszłość w dalszej części rozdziału).

Wśród nielicznych marzeń badanych gniazdowników pojawia się „marzenie o szczęściu”, „byciu szczęśliwym”, „szczęśliwej rodzinie”. Definicja „szczęścia” jest składową dwóch wcześniej wymienionych pragnień: bezpieczeństwa finansowego rozumianego jako panaceum na codzienne troski, samorealizacji oraz wsparcia rodzinnego (rodzinnej przystani. Warto jednak zauważyć, że szczęście, pomyślność, o których mówią - ex definitione - jest „czymś danym”, jest raczej zasługą losu niż własnej troski i ciężkiej pracy.

Wśród rzadkich, a jednak obecnych marzeń, znalazły się marzenia o podróży, przyjaźni i zdrowiu.

Co jednak ciekawe, sfera marzeń zaznacza charakterystyczny akcent: otóż badani często podkreślają „przyziemność” swoich marzeń („są proste”, „takie błahe”, „takie jak ma każdy”). W tej formie wypowiedzi zwraca uwagę konieczność uzasadniania swoich pragnień czyniona przez gniazdowników oraz potrzeba podkreślenia, że "gniazdujący marzyciele" nie oczekują od życia zbyt wiele. Tymczasem ich marzenia - silnie skoncentrowane na własnych potrzebach (nie zaś potrzebach osób trzecich) - dotyczą głównie pragnienia beztroski, bezpieczeństwa, spokoju, dobrobytu, innymi słowy - homeostazy - która w codziennym życiu rzadko występuje. Można zatem przyjąć, że marzenia choć 
deklarowane jako przyziemne, w gruncie rzeczy - w czasach ryzyka i w społeczeństwie ryzyka - takie nie są. Ergo, marzenia, które gniazdownicy formułują w stosunku do życia, należą do trudno osiągalnych, jeśli nie niemożliwych.

Konstruowanie życiowych planów w perspektywie $5 \mathrm{czy} 10$ lat przenosi badanych w odległą przestrzeń, w której marzenia stają się realne. Ta perspektywa w sposób szczególny pokazuje świat utęskniony dla gniazdowników, ale też rysuje miejsca - na mapie życia - które bohaterowie chcieliby zająć. Stworzony z wypowiedzi badanych obraz jest wyjątkowo spójny: praca (rozwijająca, stwarzająca awanse, jak też przynosząca zadowalające zarobki) i rodzina (zwykle z dziećmi) to współrzędne określające miejsce na ziemi, które badani kreślą w duchu oczekiwań.

W tym spójnym obrazie szczególne miejsce zajmuje jeszcze jeden istotny aspekt - przywiązanie badanych do miejsca, w którym dziś żyją i niechęć do zmiany miejscowości zamieszkania. Zważywszy na fakt, że ruchliwość przestrzenna (przemieszczanie geograficzne) jest wyraźnym atrybutem pokolenia wkraczającego w dorosłość, aspekt ten zasługuje na szczególną uwagę.

Chęć pozostania w miejscowości, w której gniazdownicy dorastają przybiera również skrajne formy (choć jednostkowe) - chęci pozostania w rodzinnym domu.

Bliscy ludzie wokół, rodzina, starzy znajomi, zaufani przyjaciele, to główny powód, dla którego gros gniazdowników chce pozostać w miejscu zamieszkania (głównie mieście czy dzielnicy).

Choć należą do nielicznych, to występują takie jednostki, które swoje życiowe plany koncentrują na wyprowadzce. Jest to jednak głos osób poszukujących swojego miejsca na ziemi (mniej lub bardziej rozpaczliwie), które dziś nie mają pomysłu na swoje życie, a wyprowadzka to forma ucieczki od niezadawalającej rzeczywistości tu i teraz. Osoby te wyraźnie negują świat i otoczenie, w którym funkcjonują („chcę być kimś więcej”, „nie chciałem żyć tak, jak ci, z którymi w tamtym czasie pracowałem, więc odszedłem”,

nie chcę żyć jak rodzice (...), nie po to jadę na urlop, tak, żeby wziąć ze sobą torbę konserw, tak? tylko po to, aby wypocząć. Nie po to, nie po to, że tak powiem, założyłem rodzinę, żeby żyć schematami utartymi. A przecież starsze pokolenia, z którymi można się spotkać, tłumaczą że oszczędzamy, oszczędzamy, jeszcze raz oszczędzamy, żeby mieć, bo nie kupię tego, bo coś tam. Nie, nie! Jeszcze raz nie!

„nie jestem zadowolona z życia w Polsce, bardzo chciałabym wyjechać z tego kraju i tak poszukuję swojej drogi”, „i tak sobie myślę czasami, żeby to wszystko rzucić i wyjechać”). Wskazane osoby brak pomysłu na siebie czerpią z suk- 
cesów i osiągnięć innych. Ten wątek jest silnie skorelowany z uzależnieniem własnego zadowolenia, jak również realizacji siebie - od innych ludzi.

Artykułowana na wstępie chęć pozostania gniazdowników w rodzinnym mieście nie wyklucza (mimo wyjątków) chęci do zakupu własnego mieszkania i wyprowadzki z rodzinnego domu. Konstruowanie życiowych planów, po raz wtóry (obok marzeń) wywołuje u badanych potrzebę uniezależnienia od rodziców, choć tylko u nielicznych. Co jednak ciekawe, nieśmiałe marzenia o wyprowadzce, które gniazdownicy artykułowali na poziomie planów i marzeń, były pacyfikowane na etapie deklaratywnych powodów gniazdowania.

\section{Podsumowanie}

W Polsce coraz więcej młodych ludzi odracza moment wyprowadzki z rodzinnego gniazda. Na tle państw europejskich plasujemy się na dziewiątej (z dwudziestu siedmiu) pozycji pod względem odsetka osób mieszkających z rodzicami, tuż obok Grecji i Portugalii. Co jednak istotne, sytuacja ekonomiczna jednostki nie decyduje w prosty sposób o gniazdowaniu, ponieważ jak wynika z badań wśród polskich gniazdowników w wieku od 25 do 34 roku życia, niezależność finansowa nie zawsze prowadzi do wyprowadzki z rodzinnego domu. Życiowe plany i dążenia gniazdowników koncentrują się głównie wokół szeroko pojętej stabilizacji, którą należy rozumieć przez pryzmat bezpieczeństwa finansowego oraz rodzinnego, ujawniając tym samym niechęć do zmian (podejmowania ryzyka) i samotności (bycia samemu). Należy zauważyć, że spełnienie tej podstawowej potrzeby (stabilizacji finansowo-rodzinnej) gwarantuje młodym układ rodzinny, w którym funkcjonują tu i teraz.

Widać wyraźnie, że choć dziś nie są gotowi do podjęcia wyzwania, jakim jest uniezależnienie od rodziny pochodzenia, to myśl ta - w formie planów czy marzeń - przebija się w ich świadomości. Póki co, potrzebę wyprowadzki racjonalizują brakiem mieszkania, pieniędzy, chęcią oszczędności, chęcią znalezienie partnera. Jakie są powody racjonalizacji? Dlaczego dziś gniazdownicy koncentrują się wokół problemów młodych ludzi raczej niż dorosłych? - na te pytania należy szukać odpowiedzi w konstelacji rodzinnej, a więc nie tylko wśród gniazdowników, ale również wśród ich rodziców, ponieważ gniazdowanie, jakkolwiek jest postawą przyjmowaną przez jednostkę, jest także doświadczeniem rodziców i pozostaje również pod wpływem ich ocen i decyzji. 


\section{Bibliografia}

Adamski F. (2002), Rodzina. Wymiar społeczno-kulturowy, Kraków

Aries P. (1995), Historia dzieciństwa. Dziecko i rodzina $w$ dawnych czasach, przeł. M. Ochab, Gdańsk

Barber R. B. (2009), Skonsumowani, Warszawa

Bauman Z. (1994), Dwa szkice o moralności ponowoczesnej, Warszawa

Beck U. (2004), Społeczeństwo ryzyka. W drodze do innej nowoczesności, S. Cieśla, Warszawa

Bogunia-Borowska M. (2006), Dziecko w świecie konsumpcji, Kraków

Buchmann M. (1989), The Script of Life In Modern Society. Entry into adulthood in Changing World, Chicago

Castells M. (1997), The Power of Identity. The information age: economy, society and culture, Malden

Cataluccio F. M., (2006), Niedojrzałość. Choroba naszych czasów, przeł. S. Kasprzysiak, Kraków

Eisenstadt S. N. (1964), From Generation to Generation. Age groups and socila structure, New York

Giddens A. (2001), Nowoczesności i tożsamość. „Ja” i społeczeństwo wepoce późnej nowoczesności, przeł. A. Szulżyńska, Warszawa

Giza-Poleszczuk A. (2005), Rodzina a system społeczny. Reprodukcja i kooperacja w perspektywie interdyscyplinarnej, Warszawa

Goldenberg H., Goldenberg I. (2006), Terapia rodzin, Kraków

Jones G. (1995), Leasing home, Buckingham

Kluzowa K. (1999), Sytuacja demograficzna rodziny polskiej lat dziewięćdziesiątych i jej konsekwencje społeczne, [w:] M. Ziemska (red.), Rodzina współczesna, Warszawa

Kocik L. (2002), Wzory małżeństwa i rodziny. Od tradycyjnej jednorodności do współczesnej skrajności, Kraków

Kurczewski J. (2003), Dziecko we współczesnej kulturze Zachodu, [w:] B. Łaciak (red.), Dziecko we współczesnej kulturze medialnej, Warszawa

Mitchell B.A. (2005), The Boomerang Age. Transition to Adulthood in Families, New Brunswick

Mead M. (2000), Kultura i tożsamość. Studium dystansu międzypokoleniowego, przeł. J. Hołówka, Warszawa

Ortega y Gasset J. (1997), Bunt mas, przeł. P. Niklewicz, Warszawa

CBOS (2005), Zależność petnoletnich dzieci od rodziców, Warszawa

Schnaiberg A., Goldenberg S. (1989), From Empty Nest to Crowded Nest: The Dynamics of Incompletely-Launched Young Adults, "Social Problems" t. 36, nr 3

Sińczuch, M. (2002), Wchodzenie $w$ dorosłość $w$ warunkach zmiany społecznej, Warszawa

Slany K. (2002), Życie w samotności, „Res Publica”, nr 12

Slany K. (2006), Alternatywne formy życia małżeńsko-rodzinnego w ponowoczesnym świecie, Kraków

Szafraniec K. (2011), Młodzi 2011, Warszawa

Szlendak T. (2010), Socjologia rodziny. Ewolucja, historia, zróżnicowanie, Warszawa

Szlendak T. (2008), Interpretacje kryzysu rodziny w socjologii. Między familijnym fundamentalizmem a rewolucja stylów życia, „Studia Socjologiczne” 4: 5-41 
Tillmann K. J. (1996), Teorie socjalizacji. Społeczność, instytucja, upodmiotowanienie, przeł. G. Bluszcz, B. Miracki, Warszawa

Zelier V.A. (1994), Pricing the priceless child. The changing social value of children, PrincetonNew Jersey

\section{Źródła internetowe}

http://www-is.phils.uj.edu.pl/publikacje/PDF/Przemiany.pdf [14.05.2005]

Kluzowa K., Slany K., 2004, Przemiany realizacji funkcji prokreacyjnej $w$ rodzinie http://www.statcan.ca/english/kits/pdf/social/nest2.pdf [6.07.2008]

Boyd M., Morris D., 1999, The Crowded Nest: Young adults at home

http://www.statcan.ca/english/freepub/11-008-XIE/2003001/articles/6552.pdf [6.07.2008]

Milan A., Peters A., 2003, Couples living apart

http://you.sagepub.com/content/14/2/119.full.pdf+html [11.11.2010]

Walther A., 2006, Regimes of youth transitions: Choice, flexibility and security in young people's experiences cross different European contexts

http://qcite.qub.ac.uk/handle/123456789/6650 [11.11.2010]

Stauber B., Walther A., 2001, Avoiding misleading trajectories: Transition dilemmas of young adults in Europe

http://appsso.eurostat.ec.europa.eu/nui/show.do?dataset=ilc_lvps08\&lang=en [20.02.2013]

Eurostat (EU - SILC) 


\section{SUMMARY}

\section{Polish Nesters. Why Are Adult Children Living With Their Parents?}

Recent social, cultural and economic changes affect the lifecycle of both families and individuals, having considerable impact on scientifically defined stages, the time dedicated to them, and developmental tasks they are associated with. One of such stages is the move of an adult child out of the family home, which is more and more often put off at the time being. The phenomenon of delaying the moment of separating yourself from your parents is referred to as nesting. Sociological and demographic studies conducted so far show that living with custodians in spite of becoming mature is getting more and more popular among young adults in Poland. In-depth analyses show that even though financial factors (low income, low purchasing power of adult children and no employment) are a significant determinant of nesting in Poland, such decisions are triggered by other motives as well. Nesting, in spite of being an individual attitude, is always a shared experience and the outcome of forces and vectors with the family ecosystem. Nesters are not the only actors of the crowded nest arrangement. Custodians and sometimes also sibling play a significant role there too. This leads to another conclusion, i.e. that nesters are not the only beneficiaries of nesting, while parents are not the only ones who bear the consequences of this co-residency.

\section{Keywords:}

nesters, young adults, adult children, parents 